\title{
POLA PEMBINAAN SOSIAL KEAGAMAAN DENGAN PENGINTEGRASIAN NILAI-NILAI BUDAYA BIMA (Studi Terhadap Para Narapidana di Lembaga Pemasyarakatan Bima)
}

\author{
Nasaruddin dan Syarifuddin \\ Institut Agama Islam (IAI) Muhammadiyah Bima \\ nasarhb@gmail.com
}

\begin{abstract}
Abstrak
Berbagai tindak kejahatan sering terjadi di masyarakat, misalnya pencurian, perampokan, penipuan, pembunuhan dan sebagainya. Dari semua tindak kejahatan tersebut terjadi dikarenakan berbagai macam faktor yang mempengaruhinya, seperti keterpaksaan seseorang melakukan tindak kejahatan pencurian yang dikarenakan faktor ekonomi, faktor lingkungan atau terikut dengan lingkungan yang ada di sekitarnya dan sebagainya. Kesemua tindak kejahatan yang terjadi tersebut harus mendapat ganjaran yang setimpal atau seimbang, dan dimasukan dalam lembaga pemasyarakatan untuk di bina dengan nilai-nila budaya lokal. Pembinaan bertujuan agar Narapidana setelah selesai menjalani masa pidananya tidak akan mengulangi perbuatannya (kejahatan) dan dapat hidup bermasyarakat secara wajar serta ikut berpartisipasi di dalam pembangunan. Maka setiap Narapidana didalam Lembaga Pemasyarakatan di bina dan di didik agar menyesali perbuatannya dan mengembangkannya menjadi Warga Binaan Pemasyarakatan yang baik dan taat kepada nilai-nilai agama dan nilai-nilai hukum. Pola pembinaan sosial keagamaan yang dilakukan oleh Lembaga pemasyarakat Bima dengan pengintegrasian nilai-nilai buadaya Bima, diantaranya Buadaya Maja Labo Dahu, Ngaha Aina Ngoho dan Nggahi Rawi Pahu.
\end{abstract}

Kata Kunci: Pembinaan Sosial, Keagamaan, Nilai-nilai, Budaya, Bima

\section{Pendahuluan}

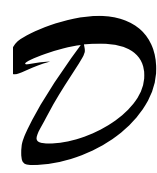

inamika kehidupan masyarakat yang cenderung kearah pola hidup konsumeristik dan materialisme pada akhirnya akan mempengaruhi sendi-sendi aqidah dan moralitas kehidupan keagamaan bahkan cenderung melakukan tindak perbuatan kriminal. Di mana pada kondisi seperti ini nilai-nilai etis adat dan budaya serta agama tidak akan banyak lagi berlaku dan diindahkan oleh masyarakat. ${ }^{1}$ Olehnya itu tindak pidana kriminalitas sebagai implikasi dari krisis akhlak dan moralitas yang melanda masyarakat, harus ada yang mencegah dan mengajaknya kembali ke jalan ma'ruf. Dalam kenyataannya laju frekwensi tindak pidana di wilayah Kabupaten dan Kota Bima menunjukkan peningkatan dari tahun-ketahun, baik secara kualitas ataupun kuantitas. Seperti maraknya perjudian, pembunuhan, penganiayaan, perampokan, penipuan, pemerasan

${ }^{1}$ Nilai etis dan budaya serta agama adalah nilai yang di junjung tinggi oleh masyarakat setempat (Masyarakat Bima Terkenal dengan Nilai Maja Labo Dahu, Ngaha Aina Ngoho dan Nggahi Rawi Pahu) dan dijadikan sebagai semboyan daerah dan falsafah hidup orang Bima. Falsafah hidup ini tidak bertentangan dengan nilai-nilai yang ada dalam al-Quran dan al-Hadits. 
(penggelapan), pembakaran rumah yang disebabkan oleh ketidak puasan antara satu pihak dan pihan yang lain, kejahatan dalam jabatan, psikotropika, kejahatan, subversi (korupsi) dan sajam (senjata tajam), perkosaan serta pembunuhan. ${ }^{2}$ Berangkat dari fakta dan fenomana tersebut para pelaku tindak kejahatan itu ditampung oleh sebuah lembaga yang dinamakan lembaga pemasyarakatan sesuai dengan undang-undang dan pasal-pasal kejahatan yang telah dieksekusi oleh pihak pengadilan, sesuai dengan kasus pelanggarannya.

Pemidanaan adalah suatu upaya untuk menyadarkan narapidana atau anak pidana agar dapat menyesali segala perbuatan yang telah dilakukannya dan mengembalikannya menjadi warga masyarakat yang baik, taat kepada hukum, menjunjung tinggi nilai-nilai moral, sosial dan keagamaan, sehingga tercapai kehidupan masyarakat yang aman, tertib dan damai. Perkembangan selanjutnya, sistem pemasyarakatan yang sudah dilaksanakan sejak tahun 1964 tersebut harus ditopang oleh payung hukum supaya lebih berartikeberadaannya. Payung hukum yang menopang sistem pemasyarakatan tersebut adalah Undang-Undang No. 12 Tahun 1995 tentang pemasyarakatan (selanjutnya disebut UUP). ${ }^{3}$ Undang-Undang Pemasyarakatan tersebut menguatkan usaha-usaha untuk mewujudkan suatu sistem pemasyarakatan yang merupakan tatanan pembinaan bagi warga binaan pemasyarakatan.

Dalam hal itu, pembinaan diharapkan agar mereka mampu memperbaiki diri dan tidak mengulangi tindakan yang bertentangan dengan hukum, sosial dan agama, lembaga pemasyarakatan(lapas) bukan hanya sebagai tempat untuk semata-mata memidana orang, melainkan juga sebagai tempat membina, juga untuk mendidik orang-orang terpidana, agar mereka setelah selesai menjalankan pidana, mempunyai kemampuan untuk menyesuaikan diri dengan kehidupan di luar lembaga pemasyarakatan sebagai warga negara yang baik dan taat kepada aturan hukum yang berlaku. Dengan Adanya sekian banyak pola pembinaan di dalam lembaga pemasyarakatan tidak terlepas dari sebuah dinamika yang tujuannya supaya warga binaan mempunyai bekal dalam menyongsong kehidupan setelah menjalani masa hukuman di lembaga pemasyarakatan.

Narapidana bukan saja sebagai objek, melainkan juga subjek yang tidak berbeda dari manusia lainnya yang sewaktu-waktu dapat melakukan kesalahan atau kekhilafan yang dapat dikenakan pidana, sehingga harus diberantas atau dimusnahkan. Sementara itu, yang harus diberantas adalah faktor-faktor yang dapat menyebabkan narapidana tersebut berbuat hal yang bertentangan dengan hukum, kesusilaan, agama, atau kewajiban-kewajiban sosial lainnya yang dapat dikenakan pidana. Dengan demikian pembinaan narapidana pada lembaga pemasyarakatan yang ada bisa menjadi sadar terhadap hukum yang ada dan tidak mengulangi lagi perbuatan tersebut, karena banyak pembinaan yang ada dalam lembaga pemasyarakatan dan menjujung tinggi nilai-nilai budaya yang ada pada setiap daerahnya,

\footnotetext{
${ }^{2}$ Hasil observasi dan pengamatan penulis tiga tahun terakhir sejak berada di Kota Bima dan Kabupaten Bima serta dalam media televise dan berita Koran baik dalam berita lokal maupun nasional.

${ }^{3}$ Peraturan Pemerintah Republik Indonesia (RI) Nomor : 31 Tahun 1999, Tentang Pembinaan dan Pembimbingan Warga Binaan Pemasyarakatan
} 
Pola Pembinaan Sosial Keagamaan Dengan Pengintegrasian Nilai-Nilai Budaya Bima (Studi Terhadap Para Narapidana di Lembaga Pemasyarakatan Bima)

(Nasaruddin \& Syarifuddin)

sehingga nilai-nilai kearifan lokal akan menjadi sumber budaya yang di jujung tinggi oleh narapidana selama nilai budaya itu tidak bertentangan dengan nilai-nila agama dan sosial. Gejala dengan segala permasalahan yang dihadapi oleh narapidana perlu kita kaji usaha penangananya dan pembinaan agar mereka dapat menjadi manusia yang berbudi luhur dan berakhlak mulia dan sadar hukum setelah keluar dari lembaga pemasyarakatan dengan beberapa pola pembinaan yang di lakukakan oleh lembaga pemasyarakatan.

\section{Landasan Teori}

\section{Konsep Pembinaan Keagamaan}

Pembinaan keagamaan yang baik terdapat dalam setiap agama, terutama agama Islam yang telah mengantarkan pemeluknya pada kehidupan yang tenang, tentram serta bahagia lahir dan batin. Kewajiban untuk menjaga keluarga sebagaimana yang difirmankan oleh Allah dalam al-Qur'an surat Attahrim ayat 6:

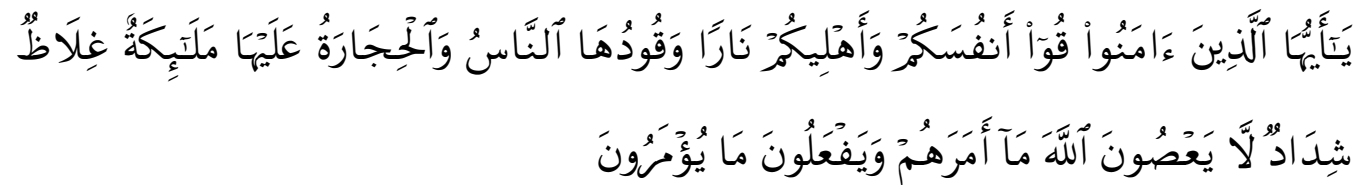

"Hai orang-orang yang beriman, peliharalah dirimu dan keluargamu dari api neraka yang bahan bakarnya adalah manusia dan batu; penjaganya malaikatmalaikat yang kasar, keras, dan tidak mendurhakai Allah terhadap apa yang diperintahkan-Nya kepada mereka dan selalu mengerjakan apa yang diperintahkan”.(QS. Attahrim[66]: 6)

Generasi sekarang ini diharapkan mampu mempertahankan kebudayaan, peradaban dan kepribadian muslim yang merupakan ciri khas Islam dan yang membedakan umat Islam dengan umat yang lain agar dapat mewariskan kepada generasi selanjutnya.

Jiwa dan mental manusia perlu di didik atau di bina guna menanamkan nilai-nilai agama pada dirinya dan keluarganya. Ketika Allah menciptakan jiwa manusia, bersamanya dia ciptakan kekuatan persiapan untuk melakukan kebaikan atau keburukan. Dia juga menjadikan manusia mampu untuk menggunakan anggota tubuh yang dikaruniakannya, tanpa ketentuan arah

Karena itu, kemenangan adalah bagi mereka yang memahami tujuan dari penciptaan, yaitu untuk beribadah kepada Allah SWT. Dengan maknanya yang menyeluruh. Demikian pula mereka mengetahui rintangan-rintangan yang menghambat mereka untuk merealisasikan tujuan ini. Diantara hambatan utamanya adalah jiwa yang ada dalam tubuh mereka orang-orang yang hening, bangkit,

${ }^{4}$ Departemen Agama Republik Inndonesia, Alquran dan Terjemahannya (Semarang ; Menara Kudus, 2006), 560. 
mensucikan diri dan meluruskan dirinya menjadi tunduk setelah sombong, lunak setelah ketakutan, dan tenang setelah terguncang. Mereka menjadi tuan atas jiwa mereka, dan mereka dapat mengendalikannya sesuai dengan yang dikehendaki Tuhan mereka. ${ }^{5}$ Jadi dasar ideal pembinaan keagamaan sudah jelas dan tegas yaitu terdapat dalam al-Qur'an dan al-Hadits. Sedangkan yang dimaksud dengan tujuan pendidikan adalah suatu faktor yang sangat penting dalam pembinaan, karena tujuan merupakan arah yang hendak di capai dan dituju.

Sasaran dan tujuan dalam pembinaan keagamaan adalah:

a. Untuk mamantapkan Aqidah

Dalam meletakkan dasar pembinaan keagamaan, harus didasarkan pada pemantapan aqidah sehingga tertanam ruh, tauhid yang dapat melahirkan pribadi muslim yang utama.

b. Untuk menyempurnakan Aqidah

Dengan tertanamnya ruh tauhid, akan mudah dalam penyempurnaan ibadah di kalangan muslim, sehingga mereka patuh dan mau mengikuti apa yang telah dicontohkan oleh Nabi Muhammad SAW.

c. Memperbaiki hubungan manusia dengan manusia

Setelah berhasil menanamkan ruh tauhid dan pelaksanaan ibadah dengan baik, maka sasaran atau tujuan pembinaan agama selanjutnya adalah untuk memperbaiki hubungan manusia dengan manusia yang lain.

Sedangkan pembahasan meteri pembinaan keagamaan bersifat universal yang mengandung aturan-aturan sebagai aspek kehidupan menusia baik yang berhubungan dengan Tuhan maupun dengan sesama manusia. Mengingat yang menjadi dasar atau referensi pembinaan keagamaan adalah al-Qur'an dan Hadits maka dapat di bayangkan bahwa materi yang akan diberikan sangat luas dan tak terhingga. Tapi petunjuk bagi para pendidik dalam memilih materi dalam pembinaan keagamaan kepada anak didiknya adalah yang di dasarkan pada nasihat Lukman kepada anaknya. Hal ini sebagainama telah di ilustrasikan dalam al-Qur'an surat Luqman ayat 13-19 materi tersebut meliputi pendidikan keimanan (aqidah), ibadah dan akhlak.

Islam sering di sebut sebagai agama yang universal, dikatakan seperti itu karena dalam ajaran-ajarannya dapat dipahami oleh siapapun, tingkat apapun dan dari lapisan manapun. Karena sasarannya dalam penelitian sekarang adalah orang dewasa. Maka materinya pun disesuaikan dengan tingkat pemahaman mereka apalagi kalau dilihat latar belakang pendidikan merekayang masih rendah, hanya sebagian kecil saja yang bisa mengenyam pendidikan SMA.

Pembahasan tentang materi agama, akan mengingatkan kita pada kurikulum sistem sekolah, sebab materi pendidikan agama adalah merupakan bagian dari

${ }^{5}$ Abdul Hamid Al-Balali, Madrasah Pendidikan Jiwa, (Jakarta: Gema Insani, 2003), 1-2. 
Pola Pembinaan Sosial Keagamaan Dengan Pengintegrasian Nilai-Nilai Budaya Bima (Studi Terhadap Para Narapidana di Lembaga Pemasyarakatan Bima)

(Nasaruddin \& Syarifuddin)

kurikulum pendidikan agama. Zuhairini, memberikan pengertian kurikulum pendidikan agama sebagai berikut:

Kurikulum pendidikan agama adalah semua pengetahuan aktivitas(kegiatan kegiatan) dan juga pengalaman yang dengan sengaja dan sistematis diberikan oleh pendidik kepada anak didik dalam rangka mencapai tujuan pendidikan agama. ${ }^{6}$

Materi yang disampaikan dalam pembinaan keagamaan, diantaranya bersifat rohaniah, pelajaran agama Islam yang mencakup:

a. Keimanan (aqidah Islam)

b. Keislaman(syariat)

c. Ikhsan (akhlak) ${ }^{7}$

Ketika inti pokok ini dijabarkan dalam bentuk rukun iman, rukun Islam dan akhlak. Maka disinilah seorang pendidik (pembina) dituntut harus bisa menjabarkan dan menjelaskan secara rasional sesuai dengan tingkat pemahaman mereka.

a. Keimanan atau Aqidah

b. Syariat atau ibadah

c. Ihsan atau Akhlak

\section{Metode Pembinaan Sosial Keagamaan}

Metode adalah suatu cara yang digunakan oleh pendidik untuk mencapai tujuan. Atau dengan kata lain yang dimaksud dengan metode pembinaan sosial keagamaan adalah segala upaya yang dilakukan dalam rangka pembentukan individu yang agamais dan beriman. Pendidik atau Pembina dalam proses pendidikan Islam tidak hanya dituntut untuk menguasai sejumlah materi yang akan diberikan kepada anak didiknya, tetapi ia harus berusaha menguasai berbagai metode dan tehnik pendidikan, guna kelangsungan informasi dan internalisasi materi pendidikan. Hal ini karena metode dan tehnik materi pendidikan Islam tidak sama dengan metode dan tehnik materi-materi pada umumnya.

Metode yang diberikan pada pembinaan keagamaanpun tidak akan jauh berbeda dengan metode yang bisa digunakan oleh seorang ibu untuk mendidik anak-anaknya. Apa yang diperoleh ibu didalam mengikuti pembinaan keagamaan bisa langsung diterapkan dan ditanamkan dalam keluarganya masing-masing.

Karena orang tua (ibu) sebagai pendidik dalam keluarga ia dituntut untuk dapat memberikan pelajaran agama Islam kepada anaknya. Banyak metode yang bisa digunakan dalam menanamkan pengetahuan agama kepada anak-anaknya salah satunya adalah dengan memberikan contoh atau keteladanan yang baik secara langsung.

${ }^{6}$ Zuhairini, Metodik Khusus Pendidikan Agama, (Usaha Nasional, 1981), 57.

${ }^{7}$ ibid., 59. 
Namun demikian dalam penerapan suatu metode perlu memperhatikan perkembangan kejiwaan anak, isi materi yang akan disampaikan serta tujuan yang ingin dicapai tersebut. Dengan kata lain, dalam pelaksanaan pendidikan agama perlu memilih metode yang baik, bijaksana sesuai dengan firman Allah SWT dalam Surat An-Nahl ayat 125:

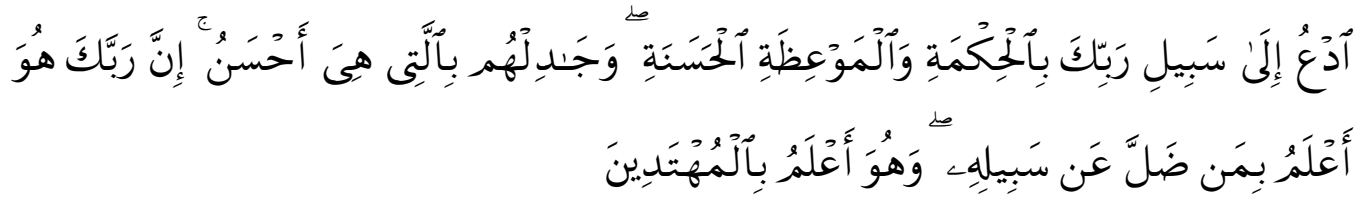

"Serulah (manusia) kepada jalan Tuhan-mu dengan hikmah ${ }^{8}$ dan pelajaran yang baik dan bantahlah mereka dengan cara yang baik. Sesungguhnya Tuhanmu dialah yang lebih mengetahui tentang siapa yang tersesat dari jalan-Nya dan dialah yang lebih mengetahui orang-orang yang mendapat petunjuk".(QS. AnNahal[16]:124) ${ }^{9}$

Secara garis besar Al-Nahlawi, menyebutkan ada tujuh pokok metode pembinaan keagamaan, yaitu dengan metode khiwar, metode kisah Al-Qur'an dan nabawi, metode amtsal, metode keteladanan, metode pembiasaan, metode ibrah dan mauidzah, metode targhib dan tarhib. Adapun penjelasan tentang metode-metode tersebut adalah: ${ }^{10}$

a. Metode Khiwar Qur'ani dan N abawi

b. Metode Amtsal (Perumpamaan)

c. Metode Pembiasaan

d. Metode Ibrah dan Mauidzoh

e. Metode Targhib wa Tarhib

f. Metode kisah

g. Metode Keteladanan

\section{Metodelogi Penelitian}

\section{Jenis Penelitian}

Penelitian ini merupakan penelitian lapangan (field study research) yang bermaksud mempelajari secara intensif tentang latar belakang, kedaan sekarang dan interaksi social, induvidu, kelompok, dan masyarakat. ${ }^{11}$ Penelitian ini merupakan studi bathil.

${ }^{8}$ Hikmah: ialah perkataan yang tegas dan benar yang dapat membedakan antara yang hak dengan yang

${ }^{9} \mathrm{Al}$-Qur'an dan Terjemahnya. 281.

${ }^{10}$ Abdurrahman An-Nahlawi, Prinsip-prinsip dan Metode Pendidikan Islam, (Diponegoro, Bandung, 1992), 204-309.

${ }^{11}$ Husaini Usman Dan Purnomo Setiadi Akbar, Metodologi Penelitian Social, (Jakarta, Bumi Aksara, 2000), 5. 
Pola Pembinaan Sosial Keagamaan Dengan Pengintegrasian Nilai-Nilai Budaya Bima (Studi Terhadap Para Narapidana di Lembaga Pemasyarakatan Bima)

(Nasaruddin \& Syarifuddin)

tentang orang-orang yang di pidana yang berada dalam lembaga pemasyarakatan, yang mengkaji tentang induvidu, kelompok dan interaksi sosial dalam lembaga pemasyarakatan, yang berupa pembinaan sosial keagamaan yang dilakukan oleh lembaga pemasyarakatan dengan harapan setelah keluar dari lapas menjadi orang yang senantiasa menjujung tinggi nilai-nilai hukum dan nilai budaya lokal.

\section{Instrumen dan Tehnik Pengumpulan Data}

Variasi pengumpulan data, erat kaitanya dengan instrumen pengumpulan data (IPD) yang digunakan. Teknik wawancara bebas, IPD yang digunakan adalah peneliti itu sendiri. Wawancara berstruktur menggunakan alat bantu pedoman wawancara. Pedoman wawancara ini dijadikan sebagai panduan sesuai dengan unsur-unsur pokok yang ditelusuri. Sedangkan pengamatan langsung menggunakan alat bantu pencatatan, matriks yang dibuat di lapangan dan juga alat kamera atau video kamera. Metode ini dipergunakan sebagai pelengkap terhadap bahan dokumenter. ${ }^{12}$

Dalam penelitian ini instrumennya adalah peneliti sendiri. Ini sesuai dengan perspektif Moleong bahwa, dalam penelitian kualitatif, instrumen yang paling tepat adalah peneliti sendiri, mengingat kedudukannya yang rumit dan beragam. Sebab, selain sebagai perencana, kolektor, analisator, dan penafsir data, sekaligus pelapor hasil penelitian. $^{13}$

Meski demikian, peneliti tidak bisa mengabaikan sama sekali instrumen bantu untuk menunjang efektivitas penelitian terhadap pertanyaan yang membutuhkan perenungan sebelum memberikan data atau jawabannya, peneliti memberikan catatan khusus. Selain itu, peneliti menggunakan perangkat keras seperti alat tulis dan media rekaman. Penggunaan alat bantu tersebut disesuaikan dengan kondisi, agar tidak mempengaruhi validitas data yang diberikan.

\section{Hasil dan Pembahasan Penelitian}

\section{Hasil Penelitian}

Berdasarkan hasil penelitian yang dilakukan oleh Peneliti bahwa: Pola Pembinaan sosial keagamaan yang Diberikan pada Narapidana di Lembaga Pemasyarakatan. Sebagaimana diketahui bahwa Sistem Pemasyarakatan yang berlaku dewasa ini, secara konseptual dan historis sangatlah berbeda dengan apa yang berlaku dalam sistem Kepenjaraan. Asas yang dianut dalam lembaga Pemasyarakatan dewasa ini menempatkan tahanan, narapidana, anak Negara dan klien pemasyarakatan sebagai subyek dan dipandang sebagai pribadi dan warga Negara biasa serta dihadapi bukan

\footnotetext{
${ }^{12}$ Lihat Kuntowijoyo, Metodelogi Sejarah, (Cet. II; Yogyakarta: PT. Tiara Wacana, 1994), 23.

${ }^{13}$ Lihat Moleong, Metode Penelitian Kualitatif, (Cet. II; Bandung: Remaja Rosda Karya, 2000), 121.
} 
dengan latar belakang pembalasan tetapi dengan pembinaan dan bimbingan. Perbedaan kedua sistem tersebut, memberi implikasi pada perbedaan dalam cara-cara pembinaan dan bimbingan yang dilakukan, disebabkan perbedaan tujuan yang ingin dicapai.

Berdasarkan hasil observasi di lembaga kemasyaraktan (LAPAS) Bima bahwa, jenis pembinaan tidak terlepas dari Peraturan Menteri Kehakiman dan hak asasi manusia (HAM). ${ }^{14}$

\begin{tabular}{|c|c|c|}
\hline No & Jenis Pembinaan & Keterangan \\
\hline 1. & $\begin{array}{l}\text { Pembinaan Kepribadian } \\
\text { a. Pembinaan kesadaran beragama } \\
\text { (kerohanian) } \\
\text { b. Pembinaan kesadaran bernegara dan } \\
\text { berbangsa. } \\
\text { c. Pembinaan intelektual (peningkatan } \\
\text { kecerdasan) } \\
\text { d. Pembinaan kesadaran hokum } \\
\text { e. Pembinan pengintegrasian diri dengan } \\
\text { masyarakat. }\end{array}$ & $\begin{array}{l}2 \text { kali seminggu } \\
1 \text { kali seminggu } \\
2 \text { kali seminggu } \\
2 \text { kali sebulan } \\
3 \text { kali seminggu }\end{array}$ \\
\hline 2 & $\begin{array}{l}\text { Pembinaan kemandirian } \\
\text { a. Keterampilan usaha mandiri } \\
\text { b. Keterampilan usaha industry } \\
\text { c. Membina bakat }\end{array}$ & $\begin{array}{l}3 \text { kali sebulan } \\
3 \text { kali sebulan } \\
2 \text { kali seminggu }\end{array}$ \\
\hline
\end{tabular}

Hal ini sesuai dengan uangkapan Kepala Lapas (KA.LAPAS) Bima pada saat peneliti mewawancarai.

Pola pembinaan yang diterapkan di LAPAS BIMA Berdasarkan Keputusan Menteri Kehakiman Republik Indonesia Nomor: M.02- PK.04.10 Tahun 1990 tentang pola pembinaan narapidana dapat dibagi ke dalam 2 bidang yakni: Pembinaan kepribadian dan pembinaan kemandirian. Dari dua pola pembinaan itu akan di rinci sesuai dengan aturan yang berlaku dan sesuai dengan kebutuhan serta kondisi yang ada. Di sisi lain ada juga perencanaan pembinaan itu tidak di laksanakan karena tidak sesuai dengan keadaan dan kondisi lembaga kemasyarakatan tetapi kita tetap berpedoman pada aturan dan keputusan menteri kehakiman. ${ }^{15}$

Secara umum dapatlah dikatakan bahwa pembinaan dan bimbingan pemasyarakatan haruslah ditingkatkan melalui pendekatan pembinaan mental (agama, Pancasila dan sebagainya) meliputi pemulihan harga diri sebagai pribadi maupun

\footnotetext{
${ }^{14}$ Data diambil dari Papan Potensi Rencana Kegiatan Pembinaan Narapidana (Napi) Lembaga Pemasyarakaran Bima Tahun 2013

${ }^{15}$ Wawancara dengan Kepala Lembaga Pemasyarakatan (KA. LAPAS BIMA), Jam 10.00 Tanggal 21 Agustus 2013 di Kantor Lapas Bima.
} 
Pola Pembinaan Sosial Keagamaan Dengan Pengintegrasian Nilai-Nilai Budaya Bima (Studi Terhadap Para Narapidana di Lembaga Pemasyarakatan Bima)

(Nasaruddin \& Syarifuddin)

sebagai warga negara yang meyakini dirinya masih memiliki potensi produktif bagi pembangunan bangsa dan oleh karena itu mereka di didik (dilatih) juga untuk menguasai ketrampilan tertentu guna dapat hidup mandiri dan berguna bagi pembangunan. Ini berarti, bahwa pembinaan dan bimbingan yang diberikan mencakup bidang mental dan ketrampilan.

Pola pembinaan yang dilakukan oleh Lembaga Pemasyarakatan terbuka berdasarkan Peraturan Pemerintah Republik Indonesia No. 28 Tahun 2006 tentang perubahan atas Peraturan Pemerintah No. 32 Tahun 1999 tentang Syarat dan Tata Cara Pelaksanaan pembinaan dalam lembaga Pemasyarakatan sehingga pola pembinaan social keagamaan tidak terlepas dari pembinaan kepribadian dan kemandirian serta social kemasyarakatan.

Didalam pembinaan ini juga kami sebagai pembina tetap menyinggung masalah nilai-nilai dan Budaya orang Bima yaitu: Maja Labo Dahu, Nggahi Rawi Pahu, Ngaha Aina Ngoho inilah yang dipegang kuat oleh etis Mbojo pada umumnya dalam berbagai ruang maupun pembagian struktur masyarakat baik elit maupun massa. Dalam ungkapan tersebut juga terlihat nilai etos kerja yang tinggi, mereka akan sangat malu jika tugas dan pekerjaan yang dilakukan tidak sukses dan berhasil dan juga takut kepada Tuhan jika cara dan methode dalam mencapai kesuksesan melanggar nilai ke-Islaman. ${ }^{16}$

Pembinaan narapidana merupakan salah satu upaya yang bersifat Ultimum Remidium (upaya terakhir) yang lebih tertuju kepada alat agar narapidana sadar akan perbuatannya sehingga pada saat kembali ke dalam masyarakat ia akan menjadi baik, baik dari segi keagaman, sosial budaya maupun moral sehingga akan tercipta keserasian dan keseimbangan di tengah-tengah masyarakat. Oleh nya itu dengan adanya pembinaan dengan pengintegrasian nilai-nilai budaya akan sadar bahwa orang Bima penuh dengan nilai-nilai lokal yang tidak bertentangan dengan nilai-nilai alQur'an dan al-Hadis. Maka akan terjadi manusia yang beriman dan beramal soleh sehingga manusia yang bukan hanya mempunyai kesolehan individual tetapi juga mempunyai kesolehan sosial.

Hal inilah yang diharapkan kepada para napi setelah selesai masa tahanannya.

Menurut keterangan narapidana dengan adanya asimilasi mereka dapat beradaptasi kembali dengan lingkungan tempat ia tinggal sebelumnya, selanjutnya menurut mereka dengan asimilasi seperti dikunjungi oleh lembagalembaga pemerintah maupun LSM mempunyai mamfaat tersendiri terlebih untuk kejiwaan mereka karena adanya kunjungan itu mereka merasa sangat terhibur dari semua rutinitas lembaga yang menjenuhkan dengan kunjungan tersebut

\footnotetext{
${ }^{16}$ Wawancara dengan Kepala Seksi Pembina dan Pendidikan di Lembaga Pemasyarakatan Bima, Hari Kamis Jam 10.00 Tanggal 18 Juli 2013
} 
tentunya ada kegiatan-kegiatan seperti ceramah agama dan pemberian keterampilan dan sebagainya. ${ }^{17}$

Pemasyarakatan membentuk sebuah prinsip pembinaan dengan sebuah pendekatan yang lebih manusiawi hal tersebut terdapat dalam usaha-usaha pembinaan yang dilakukan terhadap pembinaan dengan sistem pemasyarakatan seperti yang diatur dalam Undang-undang Nomor 12 tahun 1995 tentang pemasyarakatan. Hal ini mengandung artian pembinaan narapidana dalam system pemasyarakatan merupakan wujud tercapainya reintegrasi sosial yaitu pulihnya kesatuan hubungan narapidana sebagai individu, makhluk sosial dan makhlu Tuhan yang hidup dilingkan dengan membutuhakan pembinaan untuk menjadi manusia yang lebih baik.

\section{Pembahasan}

Dalam tulisan pembahasan ini penulis memaparkan dan membahas kembali tentang pola pembinaan yang diberikan kepada narapidan oleh petugas lapas berdasarkan aturan hasil penelitian yang ada dengan merujuk pada peraturan kementerian hukum dan HAM baik secara khusus maupun secara umum. Tujuan dari suatu proses pembinaan narapidana adalah untuk merubah perilaku yang buruk menimpang dari tatanan hidup yang tumbuh di dalam masyarakat itu sendiri, menjadi manusia yang produktif dan manusia pembangunan, artinya hasil kualitas dari suatu pembinaan itu harus lebih baik dan bermutu dari keadaan sebelumnya masuk di dalam Lembaga Pemasyarakatan ${ }^{18}$ Terkait dengan hal itu tujuan pola pembinaan narapidana di Lapas Bima diperlukan suatu pendekatan dengan pengintegrasian nilai-nilai budaya atau kearifan lokal dengan merenungi nilai-nilai budaya sebagai acuan dalam setiap langkah dan perbuatan, sehingga dalam kehidupan, tidak langsung melakukan tindakan sebelum dipikirkan lebih awalnya.

Pembinaan narapidana yang berkembang tidak hanya rehabilitasi narapidana, semakin berkembang pesatnya sehingga dalam seminar internasional mengenai kriminologi dan tentang Social Defence yang selalu mencantumkan dalam setiap item nya "The Treatment Of Offenders" yang berpangkal pada pembinaan, sehingga terbentuk "Standar Minimum Rules" dalam pembinaan narapidana dan merupakan titik terang dalam perkembangan selanjutnya di bidang "pembinaan narapidana" yang sebaik-baiknya. Standar Minimum Rules (SMR) ini antara lain menyangkut tentang bangunan penjara (lembaga), kapasitas penampungan para tahanan (narapidana) dan

${ }^{17}$ Wawancara Dengan Narapidana (NAPI) di Lembaga Pemasyarakatan Bima, Jam 11.00 Tanggal 12 Juli 2013.

${ }^{18}$ Farhan Hidayat, Pemasyarakatan Sebagai Upaya Perlindungan terhadap Masyarakat (Bandung: CV. Armico,1995), hlm.5. 
Pola Pembinaan Sosial Keagamaan Dengan Pengintegrasian Nilai-Nilai Budaya Bima (Studi Terhadap Para Narapidana di Lembaga Pemasyarakatan Bima)

(Nasaruddin \& Syarifuddin)

pedoman pembinaan atau pedoman perlakukan. ${ }^{19}$ Untuk mencapai suatu pembinaan yang berlandaskan kepada prinsip pemasyarakatan yang menjadi suatu bentuk proses pembinaan yang baru akan sempurna dalam pelaksanaannya jika didukung oleh fasilitas yang mempunyai standar yang baik dan jelas. Fasilitas pembinaan yang dimaksud adalah fasilitas yang disediakan oleh lembaga pemasyarakatan dalam usaha mengembalikan narapidana untuk menjadi manusia seutuhnya dan anggota masyarakat yang baik.

Di Lembaga Pemasyarakatan Bima menerapkan pola pembinaan narapidana berdasarkan peraturan perundang-undangan yang berlaku. Berdasarkan pasal 5 Undang-Undang No. 12 Tahun 1995 tentang pemasyarakatan yang menyatakan bahwa, sistem pembinaan pemasyarakatan dilaksanakan berdasarkan asas: Pengayoman, Persamaan perlakukan dan pelayanan, Pendidikan, Pembimbingan, Penghormatan harkat dan martabat manusia, Kehilangan kemerdekaan merupakan satu-satunya penderitaan, Terjaminnya hak untuk tetap berhubungan dengan keluarga dan orangorang tertentu.

Pemasyarakatan sebagai suatu sistem pembinaan yang pada hakekatnya merupakan suatu kegiatan yang bersifat multi dimensial, hal ini dikarenakan adanya suatu upaya pemulihan kesatuan hubungan hidup, kehidupan dan penghidupan yang merupakan masalah yang sangat kompleks. Untuk hal tersebut diperlukan pembinaan kepada warga binaan pemasyarakatan yang terdiri dari narapidana, anak didik pemasyarakatan dan klien pemasyarakatan dalam suatu kerangka pemasyarakatan, yaitu pembinaan manusia yang melibatkan semua aspek yang ada, sehingga yang terpenting dari upaya pemulihan kesatuan tersebut adalah prosesnya yang terdiri dari interaktif yang didukung oleh program pembinaan yang sesuai untuk hal tersebut. ${ }^{20}$

Proses pemasyarakatan merupakan proses integrative yang menggalang semua aspek potensi kemasyarakatan yang secara integral dan gotong-royong terjalin antara warga binaan pemasyarakatan, masyarakat dan juga petugas pemasyarakatan. Oleh karena itu dalam perspektif perlakuan terhadap warga binaan khususnya narapidana tidak mutlak harus berupa penutupan dalam lingkungan bangunan Lembaga Pemasyarakatan, mengingat yang diperlukan dalam proses pemasyarakatan adalah kontak dengan masyarakat. Pembinaan terhadap warga binaan pemasyarakatan dimulai sejak yang bersangkutan ditahan di Lembaga Pemasyarakatan sebagai tersangka atau terdakwa untuk kepentingan penyidikan, penuntutan dan pemeriksaan di sidang pengadilan. Wujud pembinaan dimaksud antara lain perawatan tahanan yaitu proses pelayanan tahanan yang dilaksanakan dimulai penerimaan sampai pengeluaran tahanan termasuk di dalamnya program-program perawatan rohani maupun jasmani

\footnotetext{
${ }^{19}$ Widiada Gunakaya. Sejarah Dan Konsepsi Pemasyarakatan, (Bandung, Armico,1996), 94

${ }^{20}$ C.I. Harsono Hs, Sistem Baru Pembinaan Narapidana (Jakarta: Kencana Pranada Media Group, 1995),
} 
Guakaya A. Widiada, ${ }^{21}$ Sistem Pemasyarakatan merupakan suatu konsep yang mempunyai prinsip-prinsip pokok yang harus dijalani antara lain:

a. Orang yang tersesat diayomi juga, dengan memberikan kepadanya bekal hidup sebagai warga yang baik dan berguna dalam masyarakat. Jelas bahwa yang dimaksud di sini adalah masyarakat Indonesia yang menuju ketaatan masyarakat yang adil dan makmur berdasarkan Pancasila. Bekal hidup diri yang tidak hanya dalam bentuk finansial dan material, tetapi lebih penting adalah mental, fisik (kesehatan), keahlian, ketrampilan, sehingga orang tersbut mempunyai kemampuan yang potensial dan efektif untuk menjadi warga negara yang baik, tidak melanggar hukum lagi, dan berguna dalam pembangunan.

b. Menjatuhi pidana bukan tindakan balas dendam dari Negara. Maksud dari hal tersebut, bahwa tidak boleh lagi ada penyiksaan terhadap para Narapidana baik berupa tindakan, ucapan, cara perawatan ataupun penempatan. Satu-satunya derita yang dialami Narapidana adalah hilang kemerdekaannya.

c. Tobat tidak dapat dicapai dengan penyiksaan, melainkan dengan bimbingan. Kepada narapidana harus ditanamkan pengertian mengenai norma-norma hidup dan kehidupan, serta diberikan kesempatan untuk merenungkan perbuatannya yang telah dilakukannya terdahulu.

d. Negara tidak berhak membuat seseorang menjadi lebih buruk/lebih jahat daripada sebelum narapidana tersebut masuk ke dalam Lembaga Pemasyarakatan. Maksud dari hal tersebut, maka harus diadakan pemisahan antara Residivis dan yang bukan, Tindak pidana berat dan tindak pidana ringan, macam tindak pidana yang dilakukan, dewasa, dewasa muda dan anak-anak, lakilaki dan wanita, orang terpidana dan orang tahanan/titipan.

e. Selama kehilangan kemerdekaan bergerak, narapidana harus di kenalkan dengan masyarakat dan tidak boleh diasingkan maksudnya di sini adalah bahwa setiap narapidana secara bertahap akan dibimbing di luar Lembaga Pemasyarakatan (di tengah-tengah masyarakat), itu merupakan suatu kebutuhan dalam proses pemasyarakatan.

f. Pekerjaan yang diberikan kepada narapidana tidak boleh bersifat mengisi waktu, atau hanya diperuntukkan kepentingan jawatan atau kepentingan Negara sewaktu saja. Pekerjaan yang diberikan harus satu dengan pekerjaan di masyarakat dan ditujukan kepada pembangunan Nasional. Maka harus ada integrasi pekerjaan narapidana dengan pembangunan Nasional.

g. Bimbingan dan didikan harus berdasarkan Pancasila. Maksud hal tersebut, bahwa pendidikan dan bimbingan yang dilakukan kepada narapidana harus berdasarkan asas-asas yang tercantum dalam Pancasila tersebut.

${ }^{21}$ Gunakaya, A. Widiada.. Sejarah dan Konsepsi Pemasyarakatan, (Bandung: CV. Armico, 1988), 103 
Pola Pembinaan Sosial Keagamaan Dengan Pengintegrasian Nilai-Nilai Budaya Bima (Studi Terhadap Para Narapidana di Lembaga Pemasyarakatan Bima)

(Nasaruddin \& Syarifuddin)

h. Tiap orang adalah manusia dan harus diperlakukan sebagai manusia, meskipun Narapidana tersebut telah tersesat. Maksud hal tersebut, bahwa tidak boleh selalu ditunjukkan kepada narapidana tersebut bahwa ia adalah seorang penjahat, sebaliknya Narapidana tersebut harus merasa bahwa ia dipandang dan diperlukan sebagai manusia.

i. Narapidana hanya dijatuhi hukuman pidana kehilangan kemerdekaan. Maksud hal tersebut, bahwa perlu diusahakan supaya Narapidana tersebutmendapat mata pencaharian untuk kelangsungan hidup keluarga yang menjadi tanggungannya, dengan disediakan pekerjaan ataupun dimungkinkan bekerja, dan diberi upah untuk pekerjaan tersebut.

j. Disediakan dan dipupuk sarana-sarana yang dapat mendukung fungsi rehabilitasi, korektif dan edukatif dalam sistem pemasyarakatan. Maksud hal tersebut, bahwa Lembaga Pemasyarakatan dituntut untuk mempunyai fasilitas sarana dan prasarana yang memadai untuk berjalannya program-program pembinaan dalam sistem pemasyarakatan sesuai dengan ketentuan yang berlaku. Pola pembinaan narapidana di Lembaga Pemasyarakatan tertutup yaitu berdasarkan Keputusan Menteri Kehakiman Republik Indonesia Nomor: M.02PK.04.10 Tahun 1990 tentang pola pembinaan narapidana. Sebagaimana yang telah diutarakan sebelumnya pada kerangka teori, bahwa berdasarkan Keputusan Menteri Kehakiman Republik Indonesia Nomor: M.02- PK.04.10 Tahun 1990 tentang pola pembinaan narapidana dapat dibagi ke dalam 2 bidang yakni:pembinaan kepribadian dan pembinaan kemandirian.

Pola pembinaan yang dilakukan oleh Lembaga Pemasyarakatan terbuka berdasarkan Peraturan Pemerintah Republik Indonesia No. 28 Tahun 2006 tentang perubahan atas Peraturan Pemerintah No. 32 Tahun 1999 tentang Syarat dan Tata Cara Pelaksanaan Hak Warga Binaan Pemasyarakatan yang salah satunya adalah hak untuk mendapat Asimilasi dengan 6 bentuk pola pembinaan, antara lain:

a. Pembinaan mental spiritual yang bertujuan untuk meningkatkan keimanan dan ketakwaan melalui kesadaran beragama. Usaha ini diperlukan untuk memberikan pengertian agar Narapidana dapat menyadari akibat dari perbuatan yang telah dilakukannya selama ini.

b. Pembinaan kesadaran berbangsa dan bernegara. Usaha ini dilaksanakan melalui pemahaman wawasan kebangsaan, termasuk menyadarkan Narapidana agar menjadi warga negara yang dapat memberikan sumbangsihnya kepada bangsa dan Negara.

c. Pembinaan kemampuan intelektual, baik melalui pendidikan formal maupun nonformal seperti program kejar paket A atau melanjutkan pendidikannya di sekolah umum. 
d. Pembinaan kesadaran hukum yang diberikan oleh Pengadilan Negeri Bima melalui penyuluhan hukum. Hakim pembinaan ini menanamkan pemahaman bagi narapidana terhadap norma dan kaedah hukum, agar tidak melanggar hukum.

e. Pembinaan kemandirian. Tujuan pembinaan ini untuk meningkatkan kemampuan narapidana melalui kegiatan kerja, antara lain program kerja perikanan, program kerja pertanian, dan program kerja peternakan.

f. Pembinaan dalam hal mengintegrasikan diri dengan masyarakat. Pengintegrasian diri ini bertujuan untuk memperbaiki hubungan narapidana dengan masyarakat di lingkungannya kelak sesudah selesai menjalani hukumannya di Lembaga Pemasyarakatan. Pembinaan tersebut memberi kesempatan untuk mengembangkan aspek-aspek pribadi yang ada pada diri Narapidana yang bersifat seluas-luasnya. Setelah melihat pola pembinaan yang dilakukan Lembaga Pemasyarakatan Bima, maka pola pembinaan di Lembaga Pemasyarkatan Bima adalah teori pencegahan dan Teori Rehabilitasi. Maksudnya teori pencegahan sesuai dengan pola pembinaan Narapidana di Lembaga Pemasyarkatan Bima, karena penjatuhan hukuman bagi para narapidana sebagai upaya membuat efek jera yang berguna untuk mencegah terulangnya kembali tindak kejahatan yang mereka perbuat sebelumnya, walaupun masih tetap saja ada yang melakukan pengulangan tetapi masih dalam tingkat yang wajar. Dan hal tersebut terjadi dikarenakan adanya kelebihan penghuni dan kekurangan petugas/pegawai Lembaga Pemasyarakatan Sedangkan maksud teori Rehabilitasi sesuai dengan pola pembinaan narapidana di Lembaga Pemasyarakatan Bima karena memang penempatan seseorang yang dikatakan sebagai narapidana di tempat tertentu yang dalam hal ini Lembaga Pemasyarakatan Bima dengan maksud membatasi kemerdekaan seseorang yang bertujuan untuk memperbaiki pelaku kejahatan agar berprilaku wajar dan pantas dengan mencantumkan norma-norma yang berlaku di masyarakat atau dapat dikatakan merehabilitasi perilaku dari pelaku tindak kejahatan atau narapidana.

Dengan adanya pembinaan para narapidana yang ada di lembaga kemasyarakatan Bima dengan pengintegrasian nilai-nilai dan budaya yang ada seperti: Maja Labo Dahu atau malu dan takut, filosofi orang Bima tidak terbatas pada orang dan golongan tertentu, tapi semua golongan : kaya, miskin, tua, muda, pejabat, maupun rakyat biasa. Indikasinya adalah segala aktifitas orang bima tetap tercermin pada prinsip tersebut, di sisi lain manusia dalam berbuat dan bertindak selalu mengevaluasi diri. Sebab, Maja Labo Dahu (malu dan takut) bukan hanya patokan tetapi cermin. Orang tua Bima selalu mengingatkan "hidup selalu bercermin pada diri". Maja Labo Dahu sesungguhnya menggugah rasa dan pikiran untuk berbuat dan bertindak secara jujur, hati-hati, teliti 
Pola Pembinaan Sosial Keagamaan Dengan Pengintegrasian Nilai-Nilai Budaya Bima (Studi Terhadap Para Narapidana di Lembaga Pemasyarakatan Bima)

(Nasaruddin \& Syarifuddin)

dan tidak gegabah. Sedangkan secara eksternal, bersikap terbuka, menghargai orang lain, ramah, memiliki kasih sayang dan saling mencintai kepada sesama.

Tidak ada hidup yang tidak saling membutuhkan. Persoalannya terletak pada kepentingan dan takaran. Secara sosiologis orang yang keluar dari takaran dan kepentingan, berada dalam ruang gerak yang tak terkendali. 'Maja Labo Dahu” tidak memiliki batas wilayah, tidak memiliki ruang gerak. Labelnya tetap mengantongi kesabaran dan kesucian. Oleh sebab itu, orang tua Bima memanifestasikan "Maja Labo Dahu" ketika anak merantau, entah menuntut ilmu atau mencari pekerjaan, berlayar atau anak menjelang upacara perkawinan.sebelum anak menapaki anak tangga pertama, sambil memegang bahu anaknya berkata "Maja Labo Dahu, anakku". 22 Ucapan tersebut disamping sebagai motivasi, juga mengandung wasiat yang harus ditaati. Bagi orang tua Bima, hanya orang yang mampu menerapkan dan menempatkan prinsip "Maja Labo Dahu” yang memiliki predikat hidup sebagai orang yang baik. Kita memekai kacamata masing-masing, anak yang menuntut ilmu tidak memperoleh Ilmu dengan baik, kehidupan keluarga baru saja menikah tapi sudah cerai atau cekcok setiap saat. Ini wujud kehidupan yang kurang dan menghayati filosofi "Maja Labo Dahu”.

Ada aspek yang dirangkum oleh "Maja Labo Dahu” dalam proses sosialisasi mmasyarakat Bima. Antara lain : Pertama, manusia mengadakan interraksi dengan dirinya. Kedua, wujud kehidupan manusia dengan manusia lainnya. Ketiga, wujud kehidupan manusia dengan lingkungannya. Keempat, wujud kehidupan manusia dengan Tuhannya ${ }^{23}$

Sejalan dengan hal tersebut di atas, dalam kitab $B O^{24}$ menjelaskan nafsu manusia amencakup beberapa perkara yang harus dijalani yaitu : perkara pertama, memakai dan memakan yang halal. Perkara yang kedua,mencari ilmu. Perkara ketiga, nggahi mapoda (perkataan yang benar). Dan perkarara keempat, kabawa weki (merendahakan diri).

Dari beberpa uraian di atas, maka peneliti menjelaskan bahwa makna filosofi Maja Labo Dahu bagi masyarakat Bima sangatlah dijunjung tinggi yang mencakup untuk berbuat baik, bertutur kata yang baik, selalu memakai dan memakan yang halal dan di dalamnya mengandung nilai luhur yang dijunjung tinggi serta ditaati oleh masrakat Bima pada umumnya.

${ }^{22}$ Anwar Hasnun, Prinsip Hidup Orang Bima, Struktur Dan Isi Pantun Bima. (Mahani Persada. Mataram, 2006), hlm. 43.

${ }^{23}$ Anwar Hasnun, Prinsip Hidup Orang Bima, Struktur Dan Isi Pantun Bima. (Mahani Persada. Mataram, 2006), hlm. 43.

${ }^{24}$ Henry Chambert-Loir Syair Kerajaan Bima. (Jakarta-Bandung; lembaga penelitia Prancis untuk timur jauh, 1982), hal 37. 
Pembinaan narapidana di Lembaga Pemasyaraka sesuai dengam keputusan menteri kehakiman republik Indonesia No : M02-PK.04.10 tahun 1990 tentang pola pembinaan narapidana dan tahanan serta undang-undang No 12 tahun 1990 tentang pemasyarakatan. ${ }^{25}$ Hanya saja pelaksanaannya belum terlaksana secara optimal yang disebabkan karena beberapa hal yaitu : kualitas sumber daya manusia; kurangnya kerja sama dengan pihak-pihak ketiga, serta sarana dan perasana yang belum memadai. Program kemandirian terhadap narapidana hendaknya dilaksanakan sesuai dengan Kebudayaan dan Karakteristik wilayah secara efektif dan kreatif serta berdaya guna untuk pengembangan kepribadian serta peningkatan tarap hidup bagi narapidana tersebut sesuai bakat, hendanya di akan memberikan dampak yang cukup besar bagi para narapidana setelah selesai menjalankan pembinaan di Lembaga Pemasyarakatan Bima.

Berangkat dari teori yang ada yaitu teori pencegahan dan rehabilitas akan melahirkan juga bahwa pencegahan dan rehabilitas membutuhkan waktu dan tempat, sehingga dalam pembinaan manusia itu tidak terlepas dalam ruang-ruang/tempat tertentu dan membutuhkan waktu yang lama. Maka lahirlah teori yang baru bahwa pembinaan manusia membutuhkan waktu dan tempat, teori ini adalah tidak bertentangan dengan teori yang ada dalam al-Quran yang berbicara masalah waktu dan lain sebagainya.

\section{Penutup}

Berdasarkan hasil penelitian dapat disimpulkan hal-hal sebagai berikut. Pada dasarnya pola pembinaan yang dilaksanakan di lembaga pemasyarakatan Kabupaten Bima/Kota Bima terbagi atas dua, yaitu: pola pembinaan kepribadian dan pola pembinaan kemandirian. Pola pembinaan kepribadian ditujukan pada pembinaan dari segi mental keagamaan, kesadaran berbangsa dan bernegara, kemampuan intelektual, kesadaran hukum, pengintegrasian diri dengan masyarakat, Sedangkan pola pembinaan kemandirian yaitu ditujukan agar narapidana memperoleh bekal untuk hidup mandiri setelah menjalani pidananya, seperti keterampilan usaha mandiri, pengembangan minat dan bakat, mendukung usaha pertanian dan perkebunan. Dari paparan hasil penelitian tersebut peneliti menemukan teori yaitu pencegahan dan rehabilitas, sehingga pencegahan dan rehabilitas itu membutuhkan waktu dan tempat untuk membina manusia. Pola pembinaan yang ada dalam lembaga pemasyarakat Bima dengan pengintegrasia nilai-nilai budaya Bima dianataranya adalah Maja Labo Dahu. ada aspek yang dirangkum oleh "Maja Labo Dahu" dalam proses sosialisasi mmasyarakat Bima. Antara lain : Pertama, manusia mengadakan interraksi dengan dirinya. Kedua, wujud

\footnotetext{
${ }^{25}$ Keputusan Menteri Kehakiman Republik Indonesia No : M02-PK.04.10 tahun 1990 Tentang Pola Pembinaan Narapidana dan Tahanan Serta Undang-Undang No 12 Tahun 1990 Tentang Pemasyarakatan.
} 
Pola Pembinaan Sosial Keagamaan Dengan Pengintegrasian Nilai-Nilai Budaya Bima (Studi Terhadap Para Narapidana di Lembaga Pemasyarakatan Bima)

(Nasaruddin \& Syarifuddin)

kehidupan manusia dengan manusia lainnya. Ketiga, wujud kehidupan manusia dengan lingkungannya. Keempat, wujud kehidupan manusia dengan Tuhannya.

\section{Daftar Pustaka}

An-Nahlawi, Abdurrahman, Prinsip-prinsip dan Metode Pendidikan Islam, Diponegoro, Bandung, 1992

C.I. Harsono Hs, Sistem Baru Pembinaan Narapidana, Jakarta: Kencana Pranada Media Group, 1995.

Departemen Agama Republik Inndonesia, Alquran dan Terjemahannya (Semarang ; Menara Kudus, 2006.

Gunakaya, Widiada. Sejarah Dan Konsepsi Pemasyarakatan, Bandung, Armico,1996.

Hamid Al-Balali, Abdul, Madrasah Pendidikan Jiwa (Jakarta: Gema Insani, 2003.

Hasnun, Anwar. Prinsip Hidup Orang Bima, Struktur Dan Isi Pantun Bima, Mahani Persada. Mataram, 2006.

Henry Chambert-Loir Syair Kerajaan Bima. (Jakarta-Bandung; lembaga penelitia Prancis untuk timur jauh, 1982

Hidayat, Farhan. Pemasyarakatan Sebagai Upaya Perlindungan terhadap Masyarakat, Bandung: CV. Armico,1995.

Husaini Usman Dan Purnomo Setiadi Akbar, Metodologi Penelitian Social, Jakarta, Bumi Aksara, 2000

Keputusan Menteri Kehakiman Republik Indonesia No : M02-PK.04.10 tahun 1990 Tentang Pola Pembinaan Narapidana dan Tahanan Serta Undang-Undang No 12 Tahun 1990 Tentang Pemasyarakatan.

Kuntowijoyo, Metodelogi Sejarah, Yogyakarta: PT. Tiara Wacana, 1994

Moleong, Lexi J. Metode Penelitian Kualitatif, Bandung: Remaja Rosda Karya, 2000

Peraturan Pemerintah Republik Indonesia (RI) Nomor : 31 Tahun 1999, Tentang Pembinaan dan Pembimbingan Warga Binaan Pemasyarakatan

Zuhairini, Metodik Khusus Pendidikan Agama, Usaha Nasional, 1981 